NOTE

\title{
Downstream impacts of a dam and influence of a tributary on the reproductive success of Leporinus reinhardti in São Francisco River
}

\author{
André Alberto Weber ${ }^{1}$, Diego Mendes Ferreira Nunes ${ }^{1}$, Rafael Zeferino Gomes ${ }^{1}$, \\ Elizete Rizzo ${ }^{2}$, Kléber Biana Santiago ${ }^{3}$, Nilo Bazzoli ${ }^{1, *}$ \\ ${ }^{1}$ Laboratório de Ictiologia, Programa de Pós-graduação em Zoologia de Vertebrados da Pontifícia \\ Universidade Católica de Minas Gerais, Belo Horizonte, Minas Gerais, Brazil \\ ${ }^{2}$ Departmento de Morfologia, Universidade Federal de Minas Gerais, Belo Horizonte, Minas Gerais, Brazil \\ ${ }^{3}$ Centro Integrado de Recursos Pesqueiros e Aquicultura de Três, CODEVASF, Minas Gerais, Brazil
}

\begin{abstract}
Downstream impacts of dams on fish fauna are poorly studied, despite causing thermal and hydrological changes that affect the reproductive activity of the fish community. The present study aims to evaluate the reproduction of Leporinus reinhardti in 2 sections of the São Francisco River, Brazil, downstream from the Três Marias Dam. Section 1 (S1) is the first $34 \mathrm{~km}$ downstream from Três Marias Dam and section 2 (S2) is 34 to $54 \mathrm{~km}$ downstream from the dam, where the São Francisco River receives a mid-sized tributary called the Abaeté River. In S1, the values of temperature, dissolved oxygen and flow were lower than those obtained in S2. In S1, females and males did not complete reproduction, a fact proven by the absence of spawned females and males. In S2, reproductive success was proven due to the presence of spawned females and males. Furthermore, the values of total length, body weight, gonadosomatic index, fecundity and vitellogenic oocytes were statistically higher than those obtained in S1. The canonical correlation test indicated that the reproduction of females is more dependent on environmental factors than that of males. In S2, L. reinhadti found appropriate conditions for reproduction, probably influenced by the Abaeté River, confirming the need of preserving this tributary for the reproductive success of this species.
\end{abstract}

KEY WORDS: Downstream impacts · Tributary · Leporinus reinhardti · São Francisco River · Spawning

\section{INTRODUCTION}

Approximately two-thirds of the largest rivers in the world have some kind of damming along their courses that has several negative impacts, the less visible of which being hydrologic alteration through the selective release of water from reservoirs (Nilsson et al. 2005, Poff et al. 2007, Olden \& Naiman 2010). The changes in downstream water parameters depend on the level of stratification of the reservoir and

\footnotetext{
${ }^{*}$ Corresponding author. Email: bazzoli@pucminas.br
}

the depth from which water is released through the turbines (Olden \& Naiman 2010).

Fish reproduction is regulated by environmental conditions that stimulate the production of sex hormones during gonadal development through the neuroendocrine-gonadal axis (Nagahama \& Yamashita 2008). Changes in environmental conditions downstream from dams may negatively affect fish populations and their reproduction (Lessard \& Hayes 2003, Sato et al. 2005), mainly due to the decrease in

() The authors 2013. Open Access under Creative Commons by Attribution Licence. Use, distribution and reproduction are unrestricted. Authors and original publication must be credited. 
temperature, which may cause a delay in spawning and embryo development and, hence, a reduction in the distribution of a species (Arantes et al. 2010, Olden \& Naiman 2010). The effects on fish populations downstream are not always negative. Unlike observations made in neotropical fishes, some temperate-water species experience reproductive success due to physico-chemical changes in the hypolimnion (e.g. temperature, dissolved oxygen, $\mathrm{pH}$, turbidity and conductivity; Miranda et al. 2012).

During the rainy season in the neotropical region, the Três Marias Dam, located on the São Francisco River, releases water downstream 2 to $3^{\circ} \mathrm{C}$ colder (hypolimnic) than temperatures that generally occurred prior to its construction in 1960 (Esteves et al. 1985). Recent studies in the area have shown that Prochilodus argenteus, a large-sized migratory species, suffers reproductive failure as a result of this change imposed by the dam (Sato et al. 2005, Arantes et al. 2010, Domingos et al. 2012, Thomé et al. 2012). However, no studies have yet analysed whether this reproductive failure also affects mid-sized species such as some fish species from the family Anostomidae.

The Anostomidae family is widely distributed in Central and South America (Garavello \& Britski

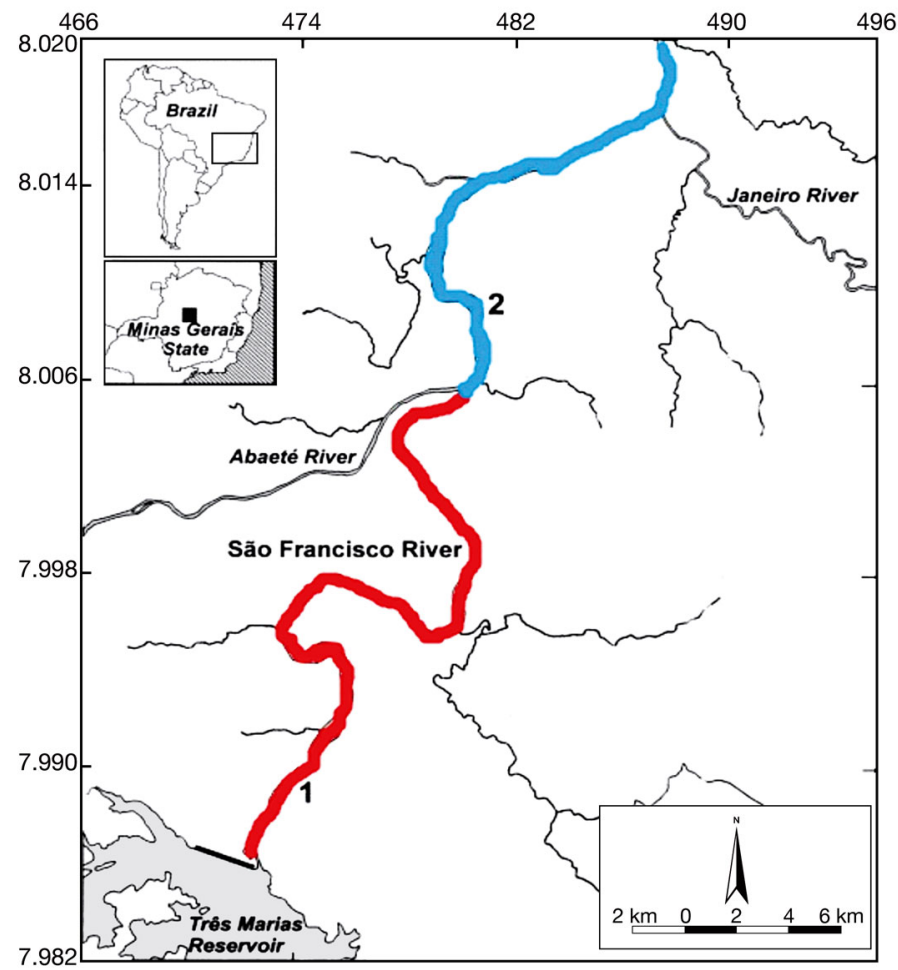

Fig. 1. Location of the study sections of the São Francisco River, downstream from the Três Marias dam. Section 1, immediately following the dam; Section 2, immediately after the confluence with the Abaeté River. UTM coordinates
2003). The piau-três-pintas Leporinus reinhardti (Lütken 1875) is a mid-sized fish endemic to the São Francisco River basin. It is abundant in the basin and an important commercial and sport-fishing species.

The aim of the present study was to compare the reproductive activity of Leporinus reinhardti in 2 sections of the São Francisco River downstream from the Três Marias dam and to analyse the impact of this dam and the importance of the Abaete River on its reproduction.

\section{MATERIALS AND METHODS}

The study analysed fish from 2 sections of the São Francisco River downstream from the Três Marias Dam: section 1 (S1), the first $34 \mathrm{~km}$ downstream from the dam $\left(18^{\circ} 11^{\prime} \mathrm{S}, 45^{\circ} 14^{\prime} \mathrm{W}\right)$ and section 2 (S2), 34 to $54 \mathrm{~km}$ downstream from the dam, after the confluence with the Abaeté River $\left(18^{\circ} 02^{\prime} \mathrm{S}, 45^{\circ} 11^{\prime} \mathrm{W}\right.$; Fig. 1). Fishes and water parameters were collected from May 2011 to April 2012 every month from different points on each section. Fishes were collected with the aid of gillnets with a mesh size of 40 to $70 \mathrm{~mm}$. A total of 562 Leporinus reinhardti were collected, 92 females and 84 males in S1 and 190 females and 196 males in S2. The fish, if alive, were killed by transversal section of the cervical medulla, following the ethical principles of animal handling established by the Brazilian College for Animal Experimentation (COBEA, www. cobea.org.br). For each specimen, total length ( $\mathrm{TL}_{\text {; }}$ to the nearest $0.01 \mathrm{~cm})$, body weight $(\mathrm{BW} ; 0.01 \mathrm{~g})$ and gonadal weight $(\mathrm{GW} ; 0.01 \mathrm{~g})$ were measured.

The following parameters were recorded for each section every month: $\mathrm{pH}$, temperature $\left({ }^{\circ} \mathrm{C}\right)$, dissolved oxygen ( $\left.\mathrm{mg} \mathrm{l}^{-1}\right)$ and specific conductance $\left(\mu \mathrm{S} \mathrm{cm}^{-1}\right)$, measured with a Horiba model $\mathrm{W}-10$ probe. Water physico-chemical parameters were measured in the 2 sections of the river every month for one year. The water flow $\left(\mathrm{m}^{3} \mathrm{~s}^{-1}\right)$ measurements were supplied by the Energy Company of Minas Gerais (CEMIG).

For each specimen, we determined the gonadosomatic index $(\mathrm{GSI}=\mathrm{GW} / \mathrm{BW} \times 100)$ and Fulton's condition factor $\left(K=\mathrm{BW} / \mathrm{TL}^{3} \times 100\right)$. The lengthweight ratio $\left(\mathrm{BW}=a \mathrm{TL}^{b}\right)$ was determined for the females and males of each section. In order to analyse the gonadal development stages, fragments of ovaries and testes were collected and fixed in Bouin's fluid for $24 \mathrm{~h}$, embedded in paraffin, sectioned at a thickness of $4 \mu \mathrm{m}$ and stained with haematoxylineosin for histological analyses.

Based on the microscopic characteristics of the gonads, the following development stages were identi- 
fied for females $(\mathrm{F})$ and males $(\mathrm{M})$ : resting (F1/M1), fully grown gonads (F2/M2) and spawned (F3/M3) (De Carvalho et al. 2009) (Fig. 2). The diameters of 50 vitellogenic oocytes (VO) from ovaries of 10 fully grown females from each section were measured using a camera attached to a light microscope and Motic Image Plus version 2.0 software. Fifteen females with fully grown ovaries, from each section of the river, were used for fecundity estimates. Absolute fecundity (AF) was estimated using the equation: $\mathrm{AF}=\mathrm{OVA} \times \mathrm{GW}$, where OVA is the number of oocytes per gram ovary. Relative fecundity (RF) was estimated using the equation: $\mathrm{RF}=\mathrm{AF} / \mathrm{BW}$.

In order to compare abiotic parameters of the water of the 2 sections, we used Student's $t$-test, and to compare biological parameters we used the MannWhitney $U$-test. We conducted canonical correlation analysis between biological parameters (TL, BW and GSI) and environmental factors (temperature, dis-
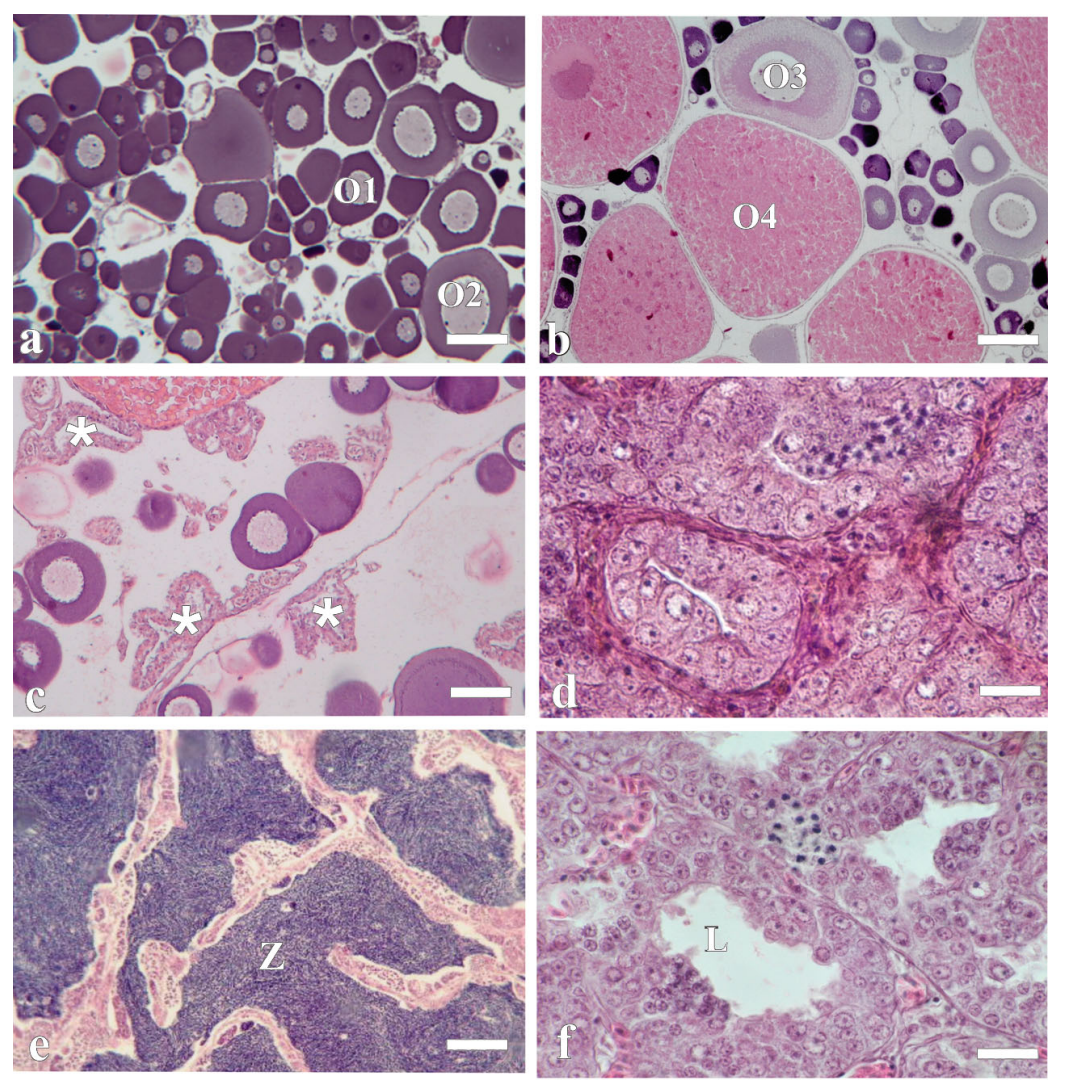

Fig. 2. Leporinus reinhardti. Gonadal development stages stained with haematoxilin-eosin. (a) Resting ovaries presented early (O1) and late (O2) perinucleolar follicles; (b) fully grown ovary emphasizing previtellogenic follicles with cortical alveoli (O3) and vitellogenic follicles $(\mathrm{O} 4)_{i}$ (c) spawned ovaries with predominance of postovulatory follicles (asterisk); (d) resting testis with seminiferous tubules closed; (e) fully grown testis with seminiferous tubules full of spermatozoa (Z), (f) spent testis open and without spermatozoa in the lumen (L). Scale bars: $(a, b, d) 70 \mu \mathrm{m}$, (c) $180 \mu \mathrm{m},(\mathrm{e}, \mathrm{f}) 30 \mu \mathrm{m}$ solved oxygen, $\mathrm{pH}$, flow and electrical conductivity) for females and males of the 2 sections, and for this analysis the data were log transformed. The software used was Bioestat 5.3 and all tests had a significance level of $\mathrm{p}<0.05$.

\section{RESULTS AND DISCUSSION}

The physical and chemical parameters of water, temperature, dissolved oxygen and flow (mean \pm SD) during the reproductive season (November to February) were significantly higher in S2 compared with $\mathrm{S} 1$ : temperature $\left(\mathrm{S} 1=23.1 \pm 0.57^{\circ} \mathrm{C}\right.$ and $\mathrm{S} 2=24.4 \pm 0.79^{\circ} \mathrm{C} ; t=-2.83, \mathrm{p}=0.03$, df =6), dissolved oxygen $\left(\mathrm{S} 1=5.5 \pm 1.67 \mathrm{mg} \mathrm{l}^{-1} ; \mathrm{S} 2=8.0 \pm\right.$ $0.55 \mathrm{mg} \mathrm{l}^{-1} ; t=-3.06, \mathrm{p}=0.01, \mathrm{df}=6$ ) and flow (S1 = $666.7 \pm 94.3 \mathrm{~m}^{3} \mathrm{~s}^{-1}$ and $\mathrm{S} 2=812.9 \pm 60.59 \mathrm{~m}^{3} \mathrm{~s}^{-1}$; $t=-2.60, \mathrm{p}=0.04, \mathrm{df}=6)$.

Females and males of Leporinus reinhardti captured in S2 showed statistically higher values of TL (females, $U=$ 2.34, $\mathrm{p}=0.02$, $\mathrm{df}=257$; males, $U=7.13$, $\mathrm{p}<0.0001, \mathrm{df}=244$ ), BW (females, $U=$ 2.17, $\mathrm{p}=0.02$, $\mathrm{df}=257$; males, $U=6.12$, $\mathrm{p}<0.0001$, $\mathrm{df}=244$ ) and GSI (females, $U=2.62, \mathrm{p}=0.01, \mathrm{df}=85$; males, $\mathrm{U}=$ $3.10, \mathrm{p}=0.01$, df $=20$ ) compared with females and males captured in S1 (Table 1). In S1, no spawned females and males were found (Fig. 3). The results of this study showed that $L$. reinhardti presents reproductive success only in S2 after the confluence with the Abaeté River and in $\mathrm{S} 1$ the reproduction of these species is not successful. This is probably due to the unfavourable conditions for somatic growth and gonadal development in S1, since, under altered thermal conditions, production and release of sex hormones such as 17- $\beta$ estradiol, which is responsible for somatic growth and gonadal development, decrease (Blázquez et al. 1998, Arantes et al. 2010). Moreover, several studies have also shown that immediately downstream from dams, the release of cold water is responsible for impaired fish reproductive activity (Clarkson \& Childs 2000, Preece \& Jones 2002, Todd et al. 2005).

VO and AF showed statistically significant differences between sections, 
Table 1. Leporinus reinhardti. Biological variables (mean \pm SD) of fish captured in 2 sections of the São Francisco River, downstream of Três Marias Dam. TL: total length; BW: body weight; GSI: gonadosomatic index (of fully grown females and males); K: Fulton's condition factor; VO: vitellogenic oocytes; AF: absolute fecundity; RF: relative fecundity. Different superscripts indicate differences between river sections $(p<0.05)$

\begin{tabular}{|c|c|c|c|c|c|c|c|c|}
\hline & Section & $\mathrm{TL}(\mathrm{cm})$ & BW (g) & GSI (\%) & $K$ & $\mathrm{VO}(\mu \mathrm{m})$ & $\mathrm{AF}\left(\times 10^{3}\right)$ & $\mathrm{RF}\left(\times 10^{2}\right)$ \\
\hline \multirow[t]{2}{*}{ Females } & $\mathrm{S} 1$ & $19.73 \pm 4.27^{\mathrm{a}}$ & $114.53 \pm 86.18^{a}$ & $11.98 \pm 5.25^{\mathrm{a}}$ & $1.34 \pm 0.24^{\mathrm{a}}$ & $545.99 \pm 61.74^{\mathrm{a}}$ & $50.68 \pm 21.96^{\mathrm{a}}$ & $2.92 \pm 1.34^{\mathrm{a}}$ \\
\hline & $\mathrm{S} 2$ & $20.93 \pm 3.77^{b}$ & $135.86 \pm 37.26^{b}$ & $16.40 \pm 5.02^{\mathrm{b}}$ & $1.32 \pm 0.22^{\mathrm{a}}$ & $571.05 \pm 51.55^{\mathrm{b}}$ & $73.20 \pm 22.28^{\mathrm{b}}$ & $4.09 \pm 1.79^{\mathrm{a}}$ \\
\hline \multirow[t]{2}{*}{ Males } & $\mathrm{S} 1$ & $14.15 \pm 2.67^{\mathrm{a}}$ & $48.49 \pm 24.35^{\mathrm{a}}$ & $0.53 \pm 0.19^{a}$ & $1.19 \pm 0.11^{\mathrm{a}}$ & - & - & - \\
\hline & $\mathrm{S} 2$ & $17.41 \pm 2.60^{\mathrm{b}}$ & $61.18 \pm 26.91^{b}$ & $0.68 \pm 0.32^{b}$ & $1.09 \pm 0.17^{b}$ & - & - & - \\
\hline
\end{tabular}
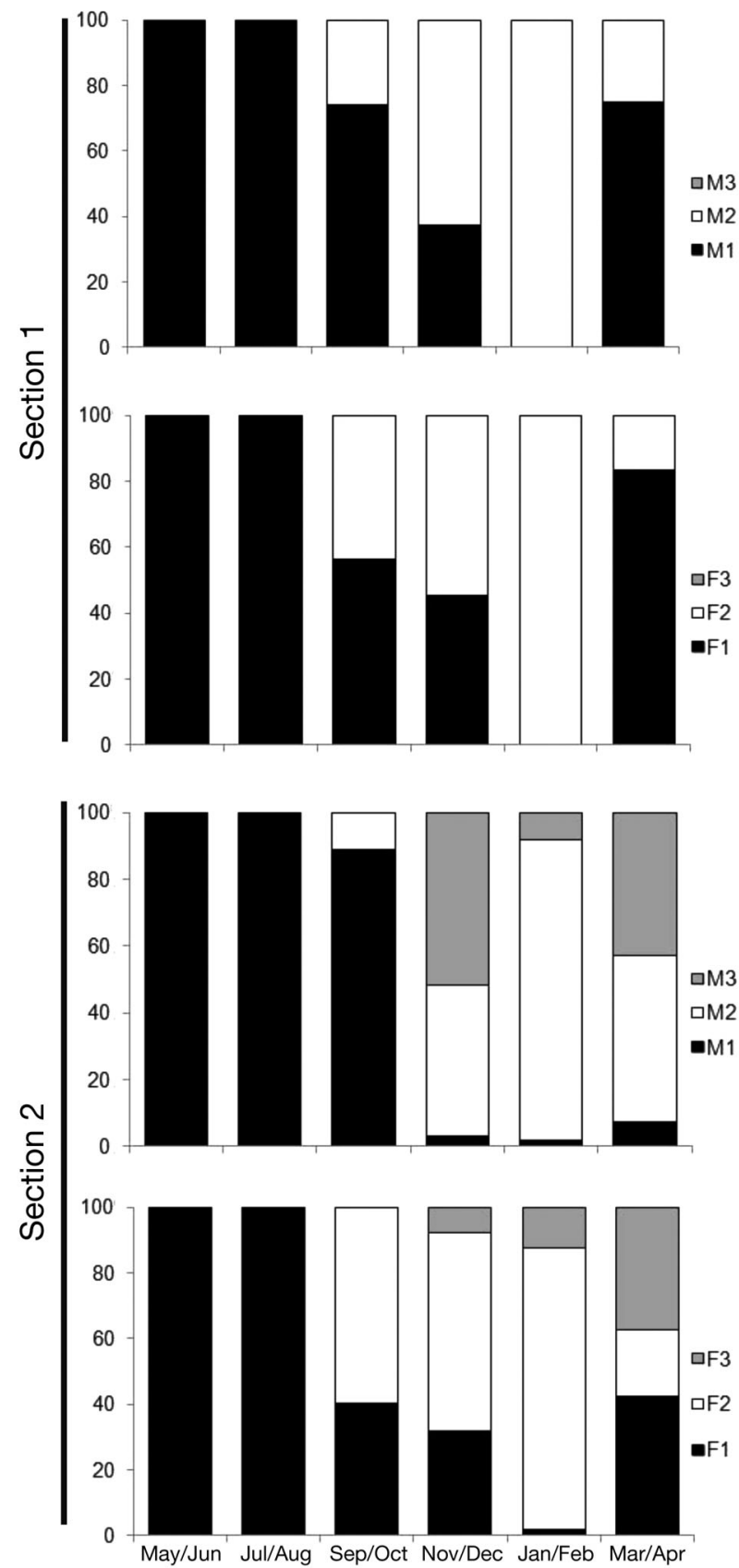

and the highest values were found in $\mathrm{S} 2(\mathrm{VO}, U=$ $2.02, \mathrm{p}=0.04, \mathrm{df}=124 ; \mathrm{AF}, U=1.96, \mathrm{p}=0.04, \mathrm{df}=18$; Table 1). In fact, higher temperatures and higher dissolved oxygen rates are contributory factors for the production of oocytes that are larger in diameter and quantity (Landry et al. 2007).

The GSI peak for females was in January/February and for males in November/December. For both sexes, the average GSI was higher in S2 than in S1 during the spawning season. The largest number of mature females and males was recorded in S2 and the largest number of resting females and males was in S1 (Fig. 3). Thus, the reproductive activity of Leporinus reinhardti coincided with the rainy season in this neotropical region, when water temperatures and river flow are higher, according to reports of Lowe-McConnell (1987). Only in S2 were postovulatory follicles observed. These structures remain in fish ovaries after ovulation and are used for confirmation of spawning (Sato et al. 2005). For Prochilodus argenteus, under the influence of a tributary, the frequency of postovulatory follicles observed was higher than observed in an area impacted by a dam (Thomé et al. 2012).

Fulton's condition factor $(K)$ showed a statistical difference between males $(U=3.66, \mathrm{p}=0.01, \mathrm{df}=$ $113)$ from the 2 sections of the river. For the females, however, this difference was not observed $(U=0.30$, $p=0.76, d f=326$; Table 1). Regarding the lengthweight ratio, females and males from the 2 sections presented a growth factor $>3$, indicating positive allometric growth for this species according to the classification of Froese (2006).

Fig. 3. Leporinus reinhardti. Relative frequency (\%) of gonadal development stages of fish captured in 2 sections of the São Francisco River, downstream from the Três Marias Dam. F1: resting ovary; M1: resting testis; F2: fully grown ovary; M2: fully grown testis; F3: spawning ovary; M3: spawning testis 
The canonical correlation $\left(R_{\mathrm{c}}\right)$ for females showed high correlation and significance between biological and environmental factors for the 2 sections (S1, $R_{\mathrm{C}}=$ 0.86, $\mathrm{p}<0.0001$, df $=25 ; \mathrm{S} 2, R_{\mathrm{C}}=0.91, \mathrm{p}<0.0001$, $\mathrm{df}=25)$. However, males of the 2 sections showed low correlation and did not show significance between biological and environmental factors (S1, $R_{\mathrm{C}}=0.25, \mathrm{p}=0.93, \mathrm{df}=20 ; \mathrm{S} 2, R_{\mathrm{C}}=0.23, \mathrm{p}=0.15, \mathrm{df}=$ $20)$. The canonical correlation shows that reproduction in males is less susceptible to environmental factors than that of females, as has also been reported for Oryzas latipes (Koger et al. 1999) and Prochilodus argenteus (Sato et al. 2005).

The results of this study showed a negative impact of the dam on the reproduction of Leporinus reinhardti in S1, and favourable conditions for the reproduction of this species in S2 of the São Francisco River. These results indicate the need for taking measures to minimise the impacts imposed by the dam, such as destratification of the water column of the Três Marias reservoir and preservation of downstream tributaries. Such measures have been taken in some countries to control the temperature of the water released downstream of dams (Vinson 2001). The conservation of dam-free tributaries is important as an alternative route for fish reproduction because these watercourses have not had their hydrological regime and physical and chemical conditions of the water changed (Pelicice \& Agostinho 2008). The degree to which a tributary helps to minimise thermal effects imposed by a dam depends on its size and its characteristics, such as flow, sediment load and water temperature (Petts 1986).

In summary, this study showed that the physical and chemical conditions of the water in S1 of the São Francisco River cause reproductive failure and that the Abaeté River is very important for the reproduction of Leporinus reinhardti.

Acknowledgements. The authors thank CEMIG-GT/ CODEVASF and the Brazilian research foundations of CNPq, CAPES and FAPEMIG for financial support, and also Stephen Latham for valuable suggestions with regard to the English language.

\section{LITERATURE CITED}

Arantes FP, Santos HB, Rizzo E, Sato Y, Bazzoli N (2010) Profiles of sex steroids, fecundity, and spawning of the curimatã-pacu Prochilodus argenteus in the São Francisco River, downstream from the Três Marias Dam, Southeastern Brazil. Anim Reprod Sci 118:330-336

Blázquez M, Bosma PT, Fraser EJ, Van Look KJW, Trudeau VL (1998) Fish as models for the neuroendocrine regulation of reproduction and growth. Comp Biochem Physiol C 119:345-364
Clarkson RW, Childs MR (2000) Temperature effects of hypolimnial-release dams on early life stages of Colorado River Basin big-river fishes. Copeia 402-412

> De Carvalho PA, Paschoalini AL, Santos GB, Rizzo E, Bazzoli N (2009) Reproductive biology of Astyanax fasciatus (Pisces: Characiformes) in a reservoir in southeastern Brazil. J Appl Ichthyol 25:306-313

> Domingos FFT, Thomé RG, Arantes FP, Castro ACS, Sato Y, Rizzo E (2012) Assessment of spermatogenesis and plasma sex steroids in a seasonal breeding teleost: a comparative study in of influence of a tributary, downstream from a hydroelectric power dam, Brazil. Fish Physiol Biochem 38:1709-1719

Esteves FA, Amorim JC, Cardoso EL, Barbosa FAR (1985) Caracterização limnológica preliminar da represa de Três Marias (MG) com base em alguns parâmetros ambientais básicos. Cienc Cult 37:608-617

Froese R (2006) Cube law, condition factor and weightlength relationships: history, meta-analysis and recommendations. J Appl Ichthyol 22:241-253

Garavello JC, Britski HA (2003) Family Anostomidae. In: Reis RE, Kullander SV, Ferraris Jr CJ (eds) Check list of the freshwater fishes of South and Central America. EDIPUCRS, Porto Alegre, p 71-84

Koger CS, Teh SJ, Hinton DE (1999) Variations of light and temperature regimes and resulting effects on reproductive parameters in medaka (Oryzias latipes). Biol Reprod 61:1287-1293

Landry CA, Steele SL, Manning S, Cheek AO (2007) Long term hypoxia suppresses reproductive capacity in the estuarine fish, Fundulus grandis. Comp Biochem Physiol A $148: 317-323$

> Lessard JL, Hayes DB (2003) Effects of elevated water temperature on fish and macroinvertebrate communities below small dams. River Res Appl 19:721-732

Lowe-McConnell RH (1987) Ecological studies in tropical fish communities. Cambridge University Press, London

Miranda R, Martínez-Lage J, Molina J, Oscoz J, Tobes I, Vilches A (2012) Ichthyofauna of a near-natural Pyrenean river: spatio-temporal variability and reach-scale habitat. Environ Eng Manag J 11:1125-1131

> Nagahama Y, Yamashita M (2008) Regulation of oocyte maturation in fish. Dev Growth Differ 50:S195-S219

Nilsson C, Reidy CA, Dynesius M, Revenga C (2005) Fragmentation and flow regulation of the world's large river systems. Science 308:405-408

> Olden JD, Naiman RJ (2010) Incorporating thermal regimes into environmental flows assessments: modifying dam operations to restore freshwater ecosystem integrity. Freshw Biol 55:86-107

> Pelicice FM, Agostinho AA (2008) Fish-passage facilities as ecological traps in large neotropical rivers. Conserv Biol 22:180-188

Petts GE (1986) Water quality characteristics of regulated rivers. Prog Phys Geogr 10:492-516

> Poff NL, Olden JD, Merritt DM, Pepin DM (2007) Homogenization of regional river dynamics by dams and global biodiversity implications. Proc Natl Acad Sci USA 104: 5732-5737

> Preece RM, Jones HA (2002) The effect of Keepit Dam on the temperature regime of the Namoi River, Australia. River Res Appl 18:397-414

Sato Y, Bazzoli N, Rizzo E, Boschi MB, Miranda MOT (2005) Influence of the Abaeté river on the reproductive success of the neotropical migratory teleost Prochilodus argen- 
teus in the São Francisco river, downstream from the Três Marias dam, southeastern Brazil. River Res Appl 21: 939-950

Thomé RG, Domingos FFT, Santos HB, Martinelli PM, Sato Y, Rizzo E, Bazzoli N (2012) Apoptosis, cell proliferation and vitellogenesis during the folliculogenesis and follicular growth in teleost fish. Tissue Cell 44:54-62

Todd CR, Ryan T, Nicol SJ, Bearlin AR (2005) The impact

Editorial responsibility: Roderick Finn,

Bergen, Norway of cold water releases on the critical period of postspawning survival and its implications for Murray cod (Maccullochella peelii peelii): a case study of the Mitta Mitta River, southeastern Australia. River Res Appl 21: 1035-1052

Vinson MR (2001) Long-term dynamics of an invertebrate assemblage downstream from a large dam. Ecol Appl 11: $711-730$

Submitted: April 5, 2013; Accepted: August 1, 2013 Proofs received from author(s): September 24, 2013 